Case Report

\title{
Asparaginase-Induced Hypertriglyceridemia Presenting as Pseudohyponatremia during Leukemia Treatment
}

\author{
Ashley Hinson, ${ }^{1}$ Dorothee Newbern, ${ }^{2}$ and Corinne M. Linardic ${ }^{1,3}$ \\ ${ }^{1}$ Department of Pediatrics, Duke University Medical Center, Box 102382, Durham, NC 27710, USA \\ ${ }^{2}$ Department of Pediatrics, Phoenix Children's Hospital, 1919 E. Thomas Road, Phoenix, AZ 85016, USA \\ ${ }^{3}$ Department of Pharmacology and Cancer Biology, Duke University Medical Center, Box 102382, Durham, NC 27710, USA
}

Correspondence should be addressed to Corinne M. Linardic; linar001@mc.duke.edu

Received 24 July 2014; Accepted 27 September 2014; Published 27 October 2014

Academic Editor: Maria Moschovi

Copyright (c) 2014 Ashley Hinson et al. This is an open access article distributed under the Creative Commons Attribution License, which permits unrestricted use, distribution, and reproduction in any medium, provided the original work is properly cited.

\begin{abstract}
Asparaginase is a chemotherapeutic agent used to induce disease remission in children with acute lymphoblastic leukemia (ALL). We describe the cases of two females with ALL who developed pseudohyponatremia as a presentation of hypertriglyceridemia following asparaginase treatment. Nine similar published cases of asparaginase-induced hypertriglyceridemia and its complications are also discussed. Possible mechanisms of action include inhibition of lipoprotein lipase, decreased hepatic synthesis of lipoprotein, and increased synthesis of VLDL. Effects of asparaginase-induced hypertriglyceridemia range from asymptomatic to transaminasemia, pancreatitis, and life-threatening thrombosis or hyperviscosity syndrome. All cases of hypertriglyceridemia described resolved following cessation of asparaginase treatment \pm further treatments.
\end{abstract}

\section{Introduction}

Asparaginase is a chemotherapeutic agent used in most remission induction protocols for children with acute lymphoblastic leukemia (ALL). It inhibits protein synthesis by depleting cellular pools of the nonessential amino acid asparagine. Normal cells can synthesize asparagine de novo via the enzyme asparagine synthase, which malignant lymphoid cells lack [1]. Despite its benefits in the treatment of ALL, asparaginase can have many adverse effects, including hypertriglyceridemia and hypercholesterolemia [2]. Here we present the cases of two children whose hyperlipidemia manifested as pseudohyponatremia. We then review the mechanisms by which asparaginase may cause hyperlipidemia and discuss implications for evaluation and treatment.

\section{Case Reports}

2.1. Patient 1. An 11-year-old female presented with leg pain, fever, and streptococcal sepsis. A complete blood count $(\mathrm{CBC})$ and peripheral blood smear revealed pancytopenia and lymphoblasts. Bone marrow evaluation showed pre-Bcell ALL. Liver function tests were slightly elevated and triglycerides (TGs) were within normal limits. She began induction chemotherapy per protocol CCG-1961 and completed treatment without complication. At a 22-month offtherapy visit, she was found to have relapsed ALL, and she began reinduction chemotherapy per protocol COGAALL0433, which included prednisone $13.3 \mathrm{mg} / \mathrm{m}^{2} /$ dose TID $\times 28$ days, as well as intermittent vincristine, doxorubicin, PEG-asparaginase $2500 \mathrm{units} / \mathrm{m}^{2}$, and intrathecal cytarabine and methotrexate. During Induction 2, she developed hyponatremia (Na $129 \mathrm{mmol} / \mathrm{L}$, normal values, 135-145). She was day three of five of scheduled cyclophosphamide and etoposide; it was presumed that her hyponatremia was due to cyclophosphamide-associated SIADH and that she might benefit from diuresis. However, that morning a vial of her blood appeared milky. A fasting lipid panel revealed marked increases in total cholesterol $(659 \mathrm{mg} / \mathrm{dL}$, normal $<180)$ and TG $(3636 \mathrm{mg} / \mathrm{dL}$, normal $<110)$ and reductions in serum HDL $(<5 \mathrm{mg} / \mathrm{dL}$, normal $>40)$. LDL $(86 \mathrm{mg} / \mathrm{dL})$ was normal. Serum ALT and bilirubin levels were elevated but 
TABLE 1: Patient 1 laboratory values before, during, and after asparaginase treatment.

\begin{tabular}{lccc}
\hline $\begin{array}{l}\text { Laboratory } \\
\text { test }\end{array}$ & $\begin{array}{c}\text { Before } \\
\text { Asparaginase }\end{array}$ & $\begin{array}{c}\text { During } \\
\text { Asparaginase }\end{array}$ & $\begin{array}{c}\text { Following } \\
\text { Asparaginase }\end{array}$ \\
\hline Sodium (mmol/L) & 139 & 129 & 137 \\
Total cholesterol (mg/dL) & 185 & 659 & 159 \\
Triglycerides (mg/dL) & 159 & 3636 & 204 \\
HDL (mg/dL) & 40 & $<5$ & 45 \\
LDL (mg/dL) & 96 & 86 & 86 \\
Amylase (U/L) & 36 & 36 & 38 \\
Lipase (U/L) & 58 & 19 & 34 \\
Total bilirubin (mg/dL) & 0.6 & 1.6 & 0.8 \\
Alkaline phosphatase (U/L) & 167 & 158 & 105 \\
AST (U/L) & 66 & $\mathrm{n} / \mathrm{a}$ & 45 \\
ALT (U/L) & 56 & 332 & 54 \\
\hline
\end{tabular}

HDL: high density lipoprotein; LDL: low density lipoprotein; AST: aspartate aminotransferase; ALT: alanine aminotransferase.

amylase and lipase were within normal limits, and she had no abdominal pain or vomiting. Correcting for the hypertriglyceridemia (corrected sodium $=$ measured sodium $+0.2 \mathrm{x}$ triglycerides in $\mathrm{g} / \mathrm{L}$ ), her serum sodium concentration was actually normal $(135 \mathrm{mmol} / \mathrm{L})$, with no medical intervention necessary. The patient had no family history of early onset hyperlipidemia or hypertriglyceridemia, nor physical exam findings of hyperlipidemia such as xanthomas. She did have a history of insulin-dependent diabetes, but her blood glucose during this period ranged from 60 to $158 \mathrm{mg} / \mathrm{dL}$ (normal 70$140 \mathrm{mg} / \mathrm{dL}$ ). She had received PEG-asparaginase one month prior, but lipid values were not checked at that time. Her TG levels decreased to $<500 \mathrm{mg} / \mathrm{dL}$ at 30 days and $200 \mathrm{mg} / \mathrm{dL}$ at 90 days without medical intervention (Table 1). Serum ALT and bilirubin also declined rapidly to near-normal levels.

2.2. Patient 2. A 3-year-old female presented with a onemonth history of fatigue and pallor. $\mathrm{CBC}$ revealed anemia and neutropenia. Bone marrow evaluation revealed pre-Bcell ALL, and she began induction chemotherapy per protocol COG-AALL0331, including dexamethasone $3 \mathrm{mg} / \mathrm{m}^{2} /$ dose BID $\times 28$ days, intermittent vincristine, PEG-asparaginase (2500 units $/ \mathrm{m}^{2}$ on day 8 ), and intrathecal cytarabine and methotrexate. On day 29 of induction, she was found to have hyponatremia $(121 \mathrm{mmol} / \mathrm{L})$, with severe hypertriglyceridemia $(3237 \mathrm{mg} / \mathrm{dL})$ and marked increases in total (1209 mg/dL) and LDL (1108 mg/dL) cholesterol, while HDL levels were normal (40-89 mg/dL). AST, ALT, and bilirubin were elevated, while amylase and lipase were normal. Given her mixed hyperlipidemia, the following formula was used to calculate a corrected sodium value: corrected serum sodium $=$ measured sodium + total lipids in $\mathrm{mmol} / 10$. (Total lipids $=$ mmol cholesterol (measured chol/39) + mmol TG (measured TG/89)) [3]. The resulting value was $127 \mathrm{mmol} / \mathrm{L}$, indicating some component of true hyponatremia in addition to pseudohyponatremia. Her cortisol and thyroid levels were normal. TG levels decreased to normal $(124 \mathrm{mg} / \mathrm{dL})$ within a week after completing induction. She did not develop complications related to her hypertriglyceridemia and as it resolved, her measured sodium, AST, ALT, and bilirubin levels also normalized (Table 2).

\section{Discussion}

3.1. Triglyceride-Induced Pseudohyponatremia. True hyponatremia is defined as a low serum sodium value associated with hypotonic extracellular fluid, which under extreme cases can cause cellular edema. Pseudohyponatremia, on the other hand, reflects a falsely low serum sodium value. Normally, serum consists of aqueous (93\%) and nonaqueous (7\%) phases, with sodium residing in the aqueous phase and glucose and lipids and proteins residing in the nonaqueous phase [3]. When serum proteins or lipids are elevated, as with patients 1 and 2, the relative fraction of nonaqueous serum becomes increased. Since serum sodium is usually measured via an indirect ion-selective electrode method, which requires dilution assuming a 93\% aqueous phase, falsely low sodium values can result. Alternative methods include direct potentiometry or ultracentrifugation; in addition, formulas exist to correct for the reduced aqueous phase [4]. In Patient 1, the falsely low serum sodium reflected an increased nonaqueous phase of serum due to elevated TG-VLDL. In Patient 2, the elevated LDL (most likely secondary to her concurrent steroid therapy) and TG-VLDL both contributed to pseudohyponatremia. Pseudohyponatremia must be recognized promptly, because if treated as true hyponatremia (with either sodium repletion or water restriction), it can lead to serious clinical complications. Instead, resolution rests in finding the source of elevated proteins, glucose, or lipids in the nonaqueous phase of the patient's serum and treating it appropriately.

3.2. Role of Corticosteroids in Lipid Elevation. Glucocorticoids are a key component of leukemia treatment and can alter lipid profiles by increasing hepatic cholesterol synthesis. When monitoring for toxicity and making treatment decisions, it is important to determine whether hypertriglyceridemia in children undergoing ALL therapy is due to 
TABle 2: Patient 2 laboratory values before, during, and after asparaginase treatment.

\begin{tabular}{lccc}
\hline $\begin{array}{l}\text { Laboratory } \\
\text { test }\end{array}$ & $\begin{array}{c}\text { Before } \\
\text { Asparaginase }\end{array}$ & $\begin{array}{c}\text { During } \\
\text { Asparaginase }\end{array}$ & $\begin{array}{c}\text { Following } \\
\text { Asparaginase }\end{array}$ \\
\hline Sodium (mmol/L) & 136 & 121 & 140 \\
Total cholesterol (mg/dL) & $\mathrm{n} / \mathrm{a}$ & 1209 & 179 \\
Triglycerides (mg/dL) & $\mathrm{n} / \mathrm{a}$ & 3237 & 75 \\
HDL (mg/dL) & $\mathrm{n} / \mathrm{a}$ & 89 & 70 \\
LDL (mg/dL) & $\mathrm{n} / \mathrm{a}$ & 1108 & 95 \\
Amylase (U/L) & 43 & 104 & 89 \\
Lipase (U/L) & 15 & 47 & 24 \\
Total bilirubin (mg/dL) & 0.4 & 3 & 176 \\
Alkaline phosphatase (U/L) & 167 & 202 & 0.8 \\
AST (U/L) & 45 & 188 & 33 \\
ALT (U/L) & 19 & 37 \\
\hline
\end{tabular}

HDL: high density lipoprotein; LDL: low density lipoprotein; AST: aspartate aminotransferase; ALT: alanine aminotransferase; n/a: not available.

steroids, asparaginase, or both. Cremer et al. [5] examined lipid profiles in two groups of ALL patients. Group 1 received prednisone and asparaginase concurrently and showed elevations in total cholesterol, TG, chylomicron TG, $\alpha$-cholesterol, and A1 apoprotein. Group 2 received prednisone first, followed by asparaginase alone, and showed elevations in $\alpha$ cholesterol and A1 apoprotein during the steroid phase, but elevations of total and chylomicron TG during asparaginase only [5]. In Parsons et al. [6], steroids were given during both induction and intensification phases, while asparaginase was given during the intensification phase only. TG elevations were only observed during the intensification phase. So, hypercholesterolemia and hypertriglyceridemia seen in ALL patients are attributed to steroids and asparaginase, respectively.

3.3. Mechanism of Asparaginase-Associated Hypertriglyceridemia. TGs derive from two sources: exogenously from the diet as chylomicrons and endogenously from hepatic VLDL synthesis. Increased TG levels result from decreased clearance or increased synthesis of TG-rich particles $[6,7]$.

3.3.1. Inhibition of Lipoprotein Lipase. TGs are cleared from the circulation by endothelial cell lipoprotein lipase (LPL), which catabolizes TG-rich particles (chylomicrons and VLDL) into fatty acids, and then taken up by adipose tissue. Conversely, decreased LPL activity causes elevated serum TGs [7]. Hoogerbrugge et al. [8] describe a 13-year-old girl with ALL who developed dramatic hypertriglyceridemia (9115 mg/dL) following asparaginase treatment. In measuring her LPL activity, they noted that while it increased during corticosteroid treatment, it decreased following asparaginase treatment, simultaneously with an increase in TG levels from $4.5 \mathrm{mmol} / \mathrm{L}$ (398 $\mathrm{mg} / \mathrm{dL}$ ) to $31.7 \mathrm{mmol} / \mathrm{L}$ (2805 mg/dL). However, when steroids and asparaginase were given concomitantly, the corticosteroid-induced rise in LPL activity was blunted [8]. Decreased asparaginase-induced LPL activity may be due to a global decrease in liver protein synthesis, as shown by decreased albumin and fibrinogen concentrations following asparaginase treatments $[5,9]$.

3.3.2. Increased VLDL Synthesis. Increased synthesis of TGrich particles may be another explanation for increased TG levels. Parsons et al. observed a large increase in VLDL during asparaginase treatment in patients with TG values $>400 \mathrm{mg} / \mathrm{dL}(70.2$ to $222 ; P=0.005)$ as compared with pretreatment values. They also measured an increase in ApoB100 (contained within VLDL particles) during asparaginase therapy, further suggesting an increase in the production of VLDL as a mechanism of hypertriglyceridemia [6].

3.4. Effects of Transient Hypertriglyceridemia following Asparaginase. Asparaginase-induced hypertriglyceridemia occurs in $10-50 \%$ of children being treated for $\operatorname{ALL}[5,6,10]$. No predisposing risk factors, dose effect, leukemia risk group, blood glucose level, gender, age, or preparation of asparaginase correlate with magnitude of TG increase. The hypertriglyceridemia is transient, with TG levels returning to normal following treatment $[8,10-13]$. Our literature search identified nine case reports of patients with elevated TG values following asparaginase therapy. Of these patients, complications included sagittal sinus thrombosis, acute pancreatitis, transaminasemia, and hyperviscosity syndrome (Table 3 ) [11-18]. Larger studies have revealed that complications, however, are rare. Steinherz examined lipid profiles of ALL patients treated with asparaginase and identified five patients with marked hyperlipidemia (TG level $>1000 \mathrm{mg} / \mathrm{dL}$ ); none of these patients experienced complications [11]. Cohen et al. evaluated cholesterol in 65 ALL patients: 18 (43\%) with TG 200-400 mg/dL, three (7\%) had levels 400-600, four (10\%) had levels 600-1000, and five (12\%) had levels $>1000 \mathrm{mg} / \mathrm{dL}$. One patient with TG $>400 \mathrm{mg} / \mathrm{dL}$ experienced complications (a left sagittal sinus thrombosis and left frontal lobe infarct) [10]. In Parsons et al., none of the patients with TG levels $>400 \mathrm{mg} / \mathrm{dL}$ or $>1000 \mathrm{mg} / \mathrm{dL}$ developed complications [6]. 
TABLE 3: Case reports in the English literature of asparaginase-induced hypertriglyceridemia.

\begin{tabular}{|c|c|c|c|c|c|c|c|c|}
\hline Age & Sex & Disease & Phase of therapy & Lipid level & Complications & Treatment & Resolution & Ref \\
\hline 9 & $\mathrm{~F}$ & T cell ALL & $\mathrm{N} / \mathrm{a}$ & $\mathrm{N} / \mathrm{a}$ & $\begin{array}{l}\text { Sagittal sinus } \\
\text { thrombosis, } \\
\text { transient diabetes } \\
\text { mellitus }\end{array}$ & $\mathrm{N} / \mathrm{a}$ & $\mathrm{N} / \mathrm{a}$ & [12] \\
\hline 10 & $\mathrm{~F}$ & $\begin{array}{l}\text { Pre-B-cell } \\
\text { ALL }\end{array}$ & Consolidation II & $\begin{array}{l}\text { Trig: } 20,600 \mathrm{mg} / \mathrm{dL} \\
\text { Chol: } 1640 \mathrm{mg} / \mathrm{dL}\end{array}$ & $\begin{array}{l}\text { Lipemia retinalis, } \\
\text { moderate } \\
\text { transaminasemia }\end{array}$ & Heparinized & $\begin{array}{l}\text { Returned to } \mathrm{nml} 2 \\
\text { weeks after } \\
\text { completion of asp } \\
\text { treatment }\end{array}$ & [11] \\
\hline 10 & $\mathrm{~F}$ & $\begin{array}{l}\text { Pre-B-cell } \\
\text { ALL }\end{array}$ & Induction & $\begin{array}{l}\text { Trig: } 1817 \mathrm{mg} / \mathrm{dL} \\
\text { Chol: } 1116 \mathrm{mg} / \mathrm{dL}\end{array}$ & $\begin{array}{l}\text { Weakness in lower } \\
\text { extremities, } \\
\text { lethargy c/w } \\
\text { hyperlipidemia- } \\
\text { associated } \\
\text { hyperviscosity } \\
\text { syndrome, } \\
\text { moderate } \\
\text { transaminasemia }\end{array}$ & $\begin{array}{l}\text { Initiation of } \\
\text { gemfibrozil and } \\
\text { omega-3 marine oil }\end{array}$ & $\begin{array}{l}\text { Improvement in } \\
\text { lipid levels and } \\
\text { liver function tests } \\
\text { with lipid-lowering } \\
\text { drugs }\end{array}$ & {$[18]$} \\
\hline 10 & M & $\mathrm{T}$ cell ALL & Induction & $\begin{array}{l}\text { Trig: } 4040 \mathrm{mg} / \mathrm{dL} \\
\text { Chol: } 540 \mathrm{mg} / \mathrm{dL}\end{array}$ & Acute pancreatitis & $\begin{array}{l}\text { Plasmapheresis, } \\
\text { removal of asp } \\
\text { from treatment } \\
\text { plan, low fat diet }\end{array}$ & Nml within 15 days & [17] \\
\hline 10 & $\mathrm{~F}$ & $\begin{array}{l}\text { Pre-B-cell } \\
\text { ALL }\end{array}$ & Maintenance & $\begin{array}{l}\text { Trig: } 2700 \mathrm{mg} / \mathrm{dL} \\
\text { Chol: } 1135 \mathrm{mg} / \mathrm{dL}\end{array}$ & Lipemia retinalis & Heparinized & $\mathrm{Nml}$ & [13] \\
\hline 13 & $\mathrm{~F}$ & $\begin{array}{l}\text { Pre-B-cell } \\
\text { ALL }\end{array}$ & Induction & $\begin{array}{l}\text { Trig: } 103 \mathrm{mmol} / \mathrm{L} \\
\text { Chol: } 7.6 \mathrm{mmol} / \mathrm{L}\end{array}$ & $\mathrm{N} / \mathrm{a}$ & $\mathrm{N} / \mathrm{a}$ & $\mathrm{N} / \mathrm{a}$ & {$[8]$} \\
\hline 16 & $\mathrm{~F}$ & $\begin{array}{l}\text { Pre-B-cell } \\
\text { ALL }\end{array}$ & Induction & $\begin{array}{l}\text { Trig: } 8510 \mathrm{mg} / \mathrm{dL} \\
\text { Chol: } 660 \mathrm{mg} / \mathrm{dL}\end{array}$ & $\begin{array}{l}\text { Lipemia retinalis, } \\
\text { moderate } \\
\text { transaminasemia, } \\
\text { lethargy, anginal } \\
\text { pain, dyspnea }\end{array}$ & $\begin{array}{l}\text { Plasmapheresis, } \\
\text { heparinized, } \\
\text { acipimox/olbetam } \\
\text { antilipidemic }\end{array}$ & Rapid nml & [15] \\
\hline 17 & $\mathrm{~F}$ & $\begin{array}{l}\text { Pre-B-cell } \\
\text { ALL }\end{array}$ & Reinduction & $\begin{array}{l}\text { Trig: } 5250 \mathrm{mg} / \mathrm{dL} \\
\text { Chol: } 672 \mathrm{mg} / \mathrm{dL}\end{array}$ & $\begin{array}{l}\text { Mild abdominal } \\
\text { pain }\end{array}$ & $\begin{array}{l}\text { Conservative } \\
\text { management }\end{array}$ & $\begin{array}{l}\text { Nml within } 3 \\
\text { weeks }\end{array}$ & [16] \\
\hline 18 & M & ALL & $\begin{array}{l}\text { End of } \\
\text { Consolidation I }\end{array}$ & Trig: 1742 mg/dL & Acute pancreatitis & $\begin{array}{l}\text { Conservative } \\
\text { management }\end{array}$ & $\begin{array}{l}\text { Nml within } 2 \\
\text { weeks }\end{array}$ & [14] \\
\hline
\end{tabular}

F: female; M: male; Trig: triglycerides; Chol: cholesterol; C/w: consistent with; Nml: normal; Asp: asparaginase; N/a: not available.

3.5. Treatment Options. There is no consensus on the optimal treatment for asparaginase-induced hypertriglyceridemia, besides cessation of asparaginase. Current therapies target the complications (Table 3 ) and include low-fat diets, fibrate therapy, heparinization, and/or plasmapheresis. Cohen et al proposed a treatment strategy for asymptomatic patients with elevated TG levels detected on routine monitoring: if TG levels $>400 \mathrm{mg} / \mathrm{dL}$ they were started on a low fat, low carbohydrate diet; if TG levels $>600 \mathrm{mg} / \mathrm{dL}$ they fasted and were hydrated intravenously; if platelets $>30,000 / \mathrm{mm}^{3}$, heparin was started. Finally, patients with TG levels $>1000 \mathrm{mg} / \mathrm{dL}$ started fibrate therapy, which was discontinued after TG decreased to $<300 \mathrm{mg} / \mathrm{dL}$ (usually within weeks of therapy initiation). None of these patients developed complications of their hypertriglyceridemia [10].

3.6. Closing and Future Directions. Asparaginase is a critical component of ALL treatment but is associated with multiple potential toxicities, including hypertriglyceridemia. We present two cases of hypertriglyceridemia presenting as pseudohyponatremia. Awareness of this metabolic side effect is imperative and could be life-saving. If not interpreted correctly, inappropriate interventions may occur (as in our cases where hyponatremia was initially thought to be due to SIADH caused by concomitant chemotherapy agents). Further studies on patient risk factors may help plan lipid monitoring protocols or guide therapies for lipid elevations.
Abbreviations
ALL: Acute lymphoblastic leukemia
HDL: High density lipoprotein
LDL: Low density lipoprotein
LPL: Lipoprotein lipase
TGs: Triglycerides
VLDL: Very low density lipoprotein. 


\section{Conflict of Interests}

The authors declare that there is no conflict of interests regarding the publication of this paper.

\section{Authors' Contribution}

Ashley Hinson, M.D., contributed to acquisition of data, analysis, interpretation, drafting, and revising of the paper, and final approval of the draft to be published. Dorothee Newbern, M.D., contributed to analysis, interpretation, revising, and final approval of the draft to be published. Corinne M. Linardic, M.D. and Ph.D., contributed to acquisition of data, analysis, interpretation, drafting, and revising of the paper, and final approval of the draft to be published.

\section{Acknowledgment}

The authors thank Michael Freemark, M.D., (Department of Pediatrics, Division of Endocrinology, Duke University Medical Center) for helpful comments and suggestions.

\section{References}

[1] J. M. Hill, J. Roberts, E. Loeb, A. Khan, A. MacLellan, and R. W. Hill, "L-asparaginase therapy for leukemia and other malignant neoplasms. Remission in human leukemia," The Journal of the American Medical Association, vol. 202, no. 9, pp. 882-888, 1967.

[2] J. M. Halton, D. J. Nazir, M. J. McQueen, and R. D. Barr, "Blood lipid profiles in children with acute lymphoblastic leukemia," Cancer, vol. 83, no. 2, pp. 379-384, 1998.

[3] P. Forgens and T. S. Pillay, "Pseudohyponatremia revisited: a modern-day pitfall," Archives of Pathology \& Laboratory Medicine, vol. 135, no. 4, pp. 516-519, 2011.

[4] L. S. Weisberg, "Pseudohyponatremia: a reappraisal," The American Journal of Medicine, vol. 86, no. 3, pp. 315-318, 1989.

[5] P. Cremer, M. Lakomek, W. Beck, and G. Prindull, "The effect of L-asparaginase on lipid metabolism during induction chemotherapy of childhood lymphoblastic leukaemia," European Journal of Pediatrics, vol. 147, no. 1, pp. 64-67, 1988.

[6] S. K. Parsons, S. X. Skapek, E. J. Neufeld et al., "Asparaginaseassociated lipid abnormalities in children with acute lymphoblastic leukemia," Blood, vol. 89, no. 6, pp. 1886-1895, 1997.

[7] A. Bensadoun, "Lipoprotein lipase," Annual Review of Nutrition, vol. 11, pp. 217-237, 1991.

[8] N. Hoogerbrugge, H. Jansen, and P. M. Hoogerbrugge, "Transient hyperlipidemia during treatment of ALL with Lasparaginase is related to decreased lipoprotein lipase activity," Leukemia, vol. 11, no. 8, pp. 1377-1379, 1997.

[9] M. Tozuka, K. Yamauchi, H. Hidaka, T. Nakabayashi, N. Okumura, and T. Katsuyama, "Characterization of hypertriglyceridemia induced by L-asparaginase therapy for acute lymphoblastic leukemia and malignant lymphoma," Annals of Clinical and Laboratory Science, vol. 27, no. 5, pp. 351-357, 1997.

[10] H. Cohen, B. Bielorai, D. Harats, A. Toren, and O. PinhasHamiel, "Conservative treatment of L-asparaginase-associated lipid abnormalities in children with acute lymphoblastic leukemia," Pediatric Blood and Cancer, vol. 54, no. 5, pp. 703706, 2010.
[11] P. Steinherz, "Transient, severe hyperlipidemia in patients with acute lymphoblastic leukemia treated with prednisone and asparaginase," Cancer, vol. 74, no. 12, pp. 3234-3239, 1994.

[12] F. Duru, U. Ertem, A. Dagdemir et al., "Coexistence of life threatening chemotherapy related leukoencephalopathy, saggital sinus thrombosis and multiple organ failure in a child with acute lymphoblastic leukemia: an unusual case with clinical recovery," Leukemia and Lymphoma, vol. 26, no. 3-4, pp. 377385, 1997.

[13] D. H. Abramson, C. A. Servodidio, P. G. Steinherz, and T. Lee, "Steroid and asparaginase-induced hyperlipidemia in leukemia," Insight, vol. 20, no. 1, pp. 12-13, 1995.

[14] Y.-K. Keung, R. Rizk, X.-Y. Wu, and E. Cobos, "Drug-induced hypertriglyceridemia with and without pancreatitis," Southern Medical Journal, vol. 92, no. 9, pp. 912-914, 1999.

[15] G. Kropshofer, G. Wehl, W. Högler, B. Meister, A. Heitger, and W. Nussbaumer, "Plasmapheresis as treatment for transient latrogenic severe hyperlipidemia in a child with leukemia," Medical and Pediatric Oncology, vol. 41, no. 2, p. 177, 2003.

[16] S. Jain, R. Naithani, G. Kapoor, and T. Nath, "l-Asparaginase induced severe hypertriglyceridemia in acute lymphoblastic leukemia with 11q23 abnormality," Leukemia Research, vol. 33, no. 11, p. e194, 2009.

[17] V. Ridola, P. S. Buonuomo, P. Maurizi et al., "Severe acute hypertriglyceridemia during acute lymphoblastic Leukemia induction successfully treated with plasmapheresis," Pediatric Blood and Cancer, vol. 50, no. 2, pp. 378-380, 2008.

[18] F. Athanassiadou, M. Kourti, T. Papageorgiou, M. Stamou, A. Makedou, and A. Boufidou, "Severe hyperlipidemia in a child with acute lymphoblastic leukemia treated with L-asparaginase and prednisone," Pediatrics International, vol. 46, no. 6, pp. 743744, 2004. 


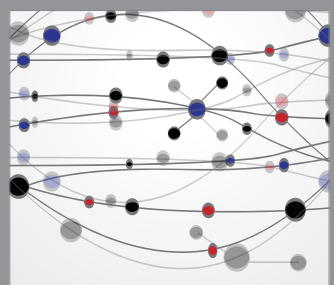

The Scientific World Journal
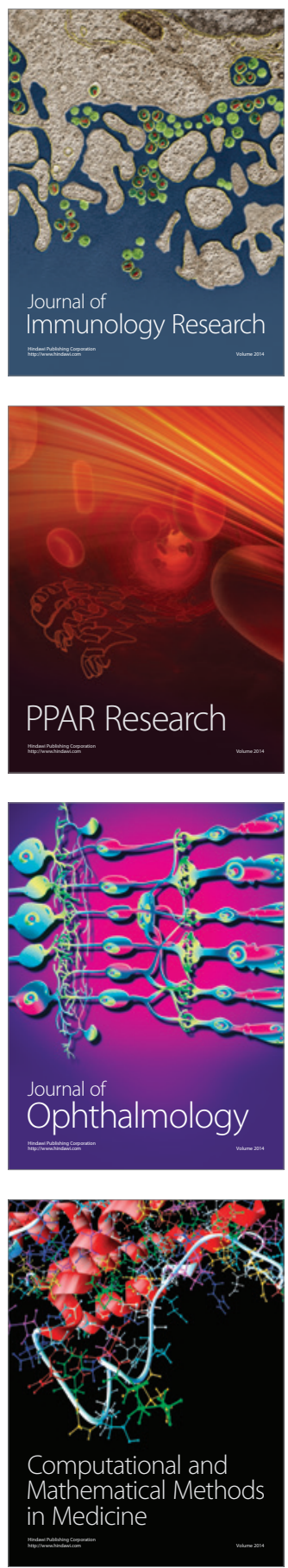

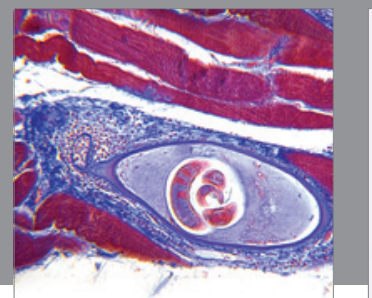

Gastroenterology

Research and Practice
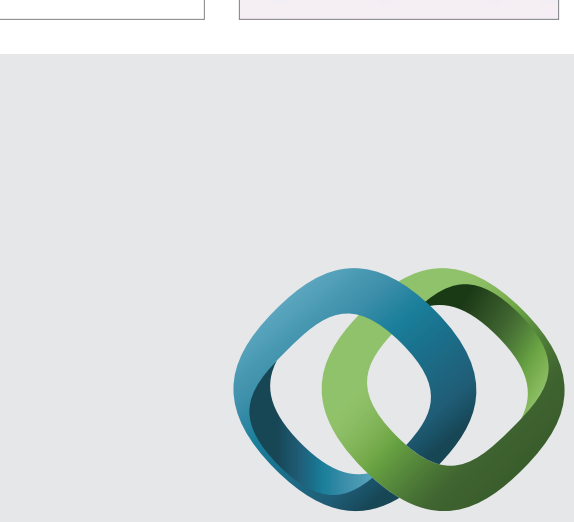

\section{Hindawi}

Submit your manuscripts at

http://www.hindawi.com
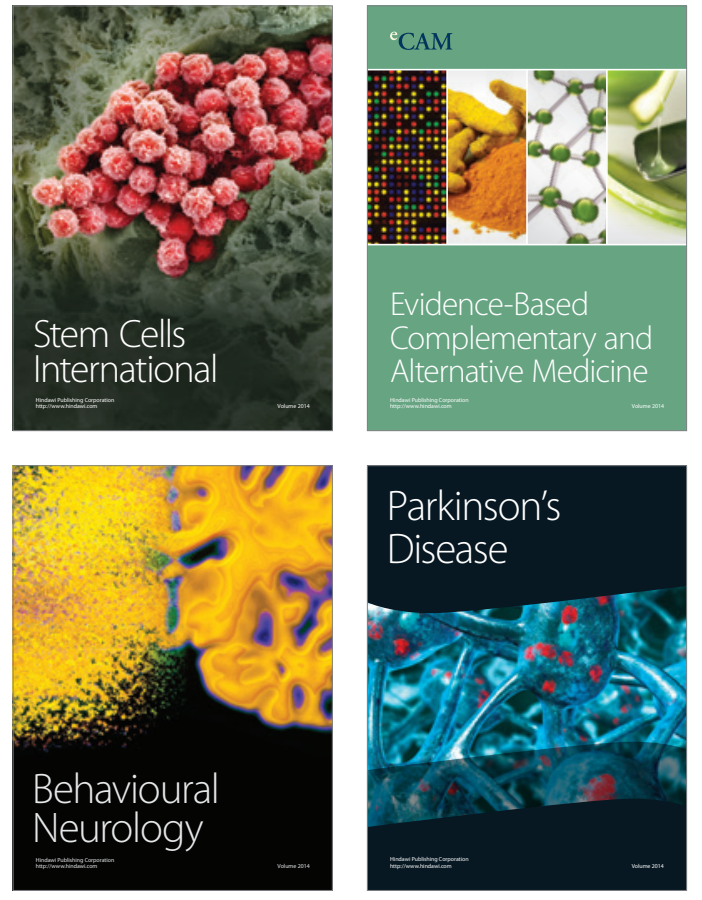
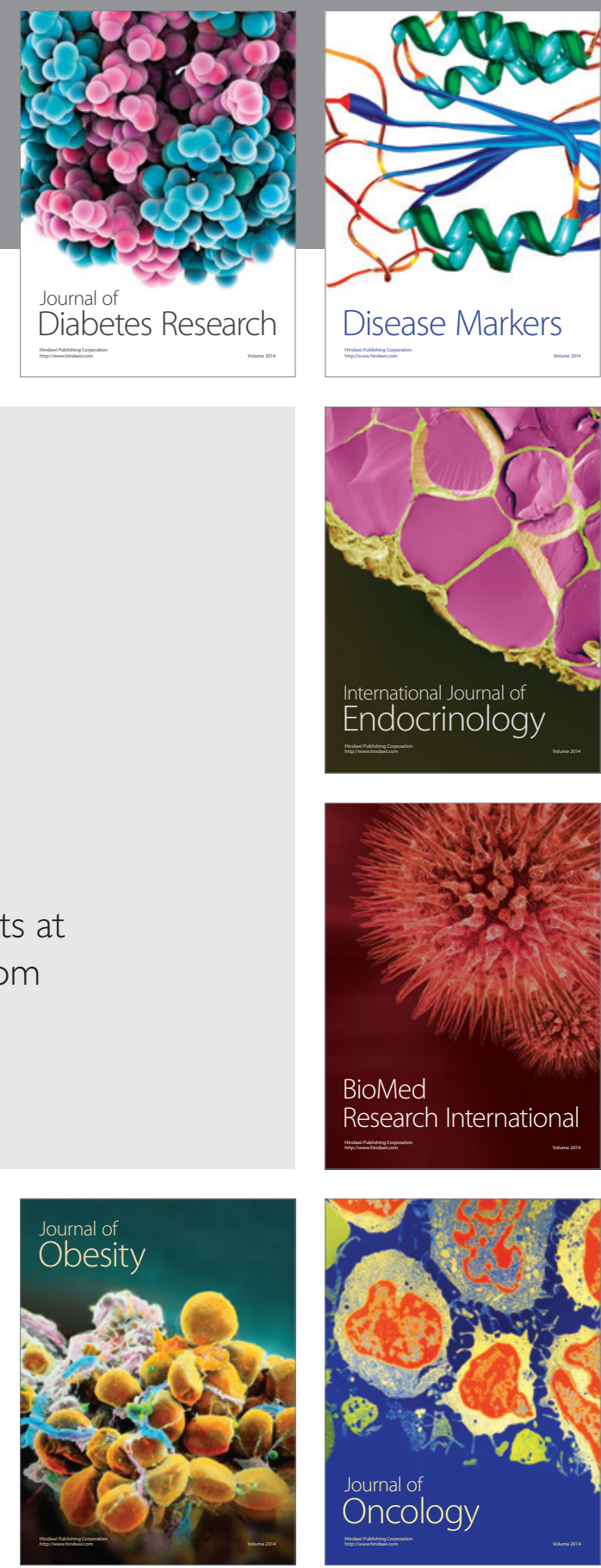

Disease Markers
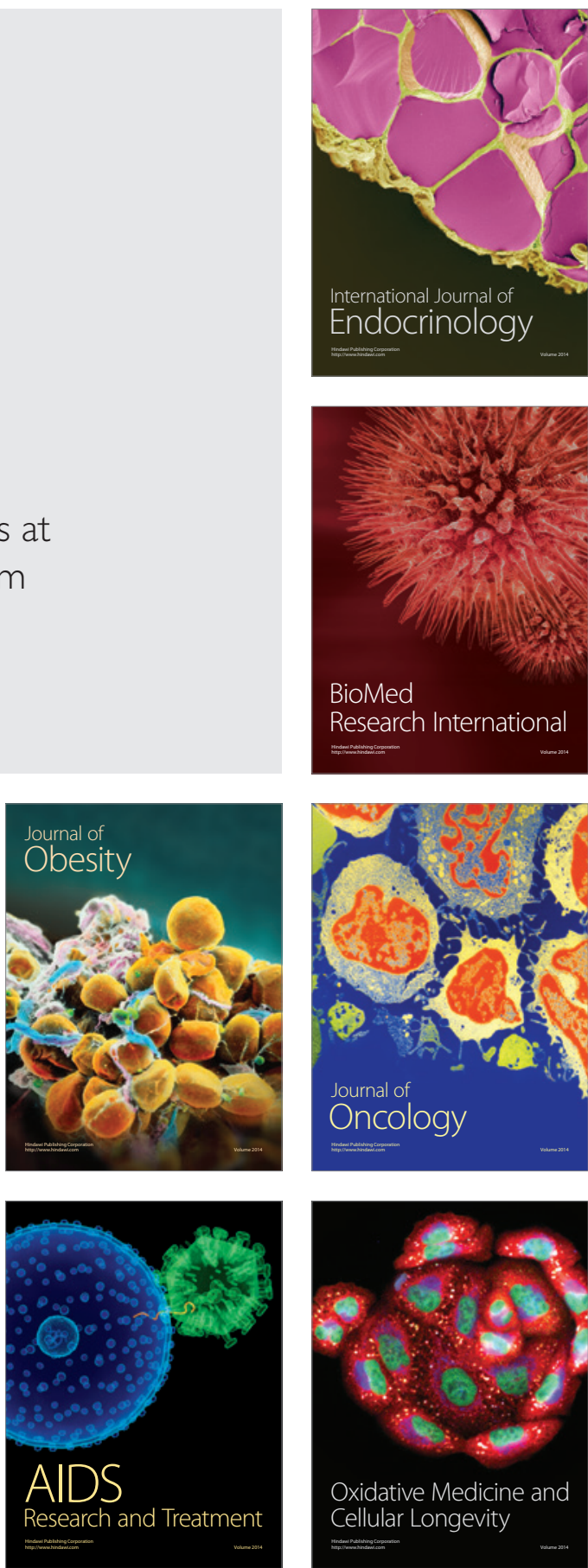